Article

\title{
Climate Smart Regenerative Agriculture to Produce Sustainable Beauty Products: The Case Study of Snail Secretion Filtrate $\left(\mathrm{LX} 360^{\circledR}\right)$
}

\author{
Agata Novara ${ }^{1, *}$, Salvatore Sampino ${ }^{1}$, Fernando Paternò ${ }^{1}$ and Saskia Keesstra ${ }^{2,3}$ (D) \\ 1 Department of Agricultural, Food and Forest Sciences, University of Palermo, Viale delle Scienze, Ed 4, \\ 90100 Palermo, Italy; salvo.sampino@libero.it (S.S.); agr.fpaterno@gmail.com (F.P.) \\ 2 Team Soil Water and Land Use, Wageningen Environmental Research, Wageningen University \& Research, \\ 6700 AA Wageningen, The Netherlands; saskia.keesstra@wur.nl \\ 3 Department of Civil, Surveying and Environmental Engineering, The University of Newcastle, Callaghan, \\ NSW 2308, Australia \\ * Correspondence: agatanovara@gmail.com
}

check for updates

Citation: Novara, A.; Sampino, S.; Paternò, F.; Keesstra, S. Climate Smart Regenerative Agriculture to Produce Sustainable Beauty Products: The Case Study of Snail Secretion Filtrate $\left(\mathrm{LX} 360^{\circledR}\right)$. Sustainability 2022, 14, 2367. https://doi.org/10.3390/ su14042367

Academic Editor: Jeroen Meersmans

Received: 16 December 2021

Accepted: 15 February 2022

Published: 18 February 2022

Publisher's Note: MDPI stays neutral with regard to jurisdictional claims in published maps and institutional affiliations.

Copyright: (C) 2022 by the authors. Licensee MDPI, Basel, Switzerland. This article is an open access article distributed under the terms and conditions of the Creative Commons Attribution (CC BY) license (https:// creativecommons.org/licenses/by/ $4.0 /)$.

\begin{abstract}
In the last years, the environmental impacts of cosmetics production have received growing interest from consumers, industries and the scientific community. Therefore, the selection and evaluation of more sustainable ingredients for cosmetic preparations need greater attention. The purpose of this work was to evaluate the environmental impact of snail secretion filtrate (LX360 $\left.{ }^{\circledR}\right)$, which could be used as an alternative cosmetic ingredient. The Carbon Footprint (CF) was used to quantify the $\mathrm{kgCO}_{2}$ eq per liter of the $\mathrm{LX}_{360^{\circledR}}$ produced in a rearing system farm that follows circularity economy and regenerative agriculture principles. The study computes the soil organic carbon (SOC) stock change due to the implementation of regenerative agricultural practices. The $\mathrm{CF}$ of the production system was up to $1.76 \mathrm{~kg} \mathrm{CO}_{2} \mathrm{eq} \mathrm{L}^{-1}$, where the extraction stage contributed most. Findings on SOC stock showed a significant increase compared to the previous land-use. The net sequestered $\mathrm{CO}_{2}$ into the soil amounts to $2.07 \mathrm{~kg} \mathrm{CO}_{2} \mathrm{eq} \mathrm{L}^{-1}$; therefore, the production of $\mathrm{LX} 360^{\circledR}$ showed a positive carbon balance $\left(0.31 \mathrm{~kg} \mathrm{CO}_{2} \mathrm{eq} \mathrm{L}^{-1}\right)$. The application of regenerative agriculture in snail rearing systems positively affects SOC sequestration, and it should be considered as a best management practice for the restoration of degraded land.
\end{abstract}

Keywords: circular economy; cosmetics; carbon sequestration; Helix aspersa muller; soil restoration; carbon footprint

\section{Introduction}

In recent years, heliciculture (snail farming) has spread in several European countries. It has proven to be a profitable market activity, both for the production of food and for cosmetics (Forte et al., 2016) [1]. European countries are the largest consumers, and the global snail meat market is progressively increasing. Spain is the country with the highest consumption $\left(16.5 \times 10^{3}\right.$ tons $)$, followed by Morocco $\left(6 \times 10^{3}\right.$ tons $)$, France $\left(5.3 \times 10^{3}\right.$ tons $)$ and Italy $\left(2.1 \times 10^{3}\right.$ tons) [2]. A notable benefit of snail farming is that snails require lower inputs to grow and produce the same amount of protein-rich meat compared to cows, pigs, and poultry, and therefore particular attention has been paid to snail farming in recent years since it could be an alternative protein source with a lower environmental impact.

Forte et. [1] evaluated the greenhouse gas emissions (GHG) of snail meat production, considering the whole life cycle from indoor breeding and outdoor fattening up to the packaging stage in a semi-intensive rearing system. The authors estimated that the carbon footprint of snail meat is $0.7 \mathrm{~kg} \mathrm{CO}$ per $1 \mathrm{~kg}$ of edible meat, while for $1 \mathrm{~kg}$ of beef, values range from 14 to $51 \mathrm{~kg} \mathrm{CO}$ per $1 \mathrm{~kg}$ in relation to the production system [3,4]. Although these values are lower than other protein production [1,5], the impact of snail farming 
could become relevant considering the rapid spread of snail farming. In Italy, there are approximately 7000 snail farms, covering a surface of 5.200 ha [1], of which $83 \%$ are characterised by an extensive rearing system. The success of snail farming is due to low capital investment, and it is considered a new opportunity for rural development and as an alternative profitable livestock system [6,7].

Studies on the life cycle assessment of snail rearing and consequent carbon footprint analysis showed that the highest impact on GHG emission occurs in the breeding and fattening stage. In their life cycle assessment analysis, Forte et al. [1] showed that colza and sunflower fertilization is the primary source of $\mathrm{CO}_{2}$ emission in snail meat production. Therefore, new climate-smart mitigation strategies for the most impactful cultivation stages are needed. The application of best management practices and the reduction of external input could be helpful to reduce the impact on climate change, increasing the soil organic carbon (SOC) stock sequestration. In a carbon budget analysis under different management scenarios, Novara et al. [8] showed that applying cover crop management in semiarid vineyards does not only reduce erosion but also increases soil organic matter, reducing the carbon footprint (CF) of wine growing. Among alternative agronomic management to conventional and intensive farming systems, regenerative agriculture could contribute to mitigating climate change. Regenerative farming systems [9] aim to increase soil chemical and biological fertility through abandoning tillage, eliminating spatio-temporal events of bare soil, increasing plant diversity, integrating livestock and cropping land uses, and not using agrochemicals [10]. The application of regenerative agriculture practices has shown several benefits to restoring soil fertility and crop efficiency in cultivated drylands [11,12]. According to the result of recent meta-analyses, regenerative agriculture practice has proven to be beneficial for climate mitigation in the most widespread rainfed woody crops, such as vineyards, olives, and orchards [13,14]; however, very few studies have yet been performed on agroforestry systems. Heliciculture is expanding not only for human food but also for the production of medicines and cosmetics. The global snail beauty products market accounted for US \$3.7 billion in 2019 and is estimated to be US \$12.0 billion by 2029 [15]. Snail secretion is an active natural substance used in cosmetic creams and syrups thanks to its emollient, reparative, protective, and moisturizing features [16,17]. Moreover, recent studies have demonstrated that snail secretion also has anti-tumoral characteristics against human melanoma cells and broncho-relaxant effects [18,19].

In light of the increase in interest in snail secretion, especially in cosmetics, as an environmentally friendly raw material, there is a need to evaluate the impact of the rearing system on the environment and to develop alternative management strategies for sustainable production.

The purpose of this research was to quantify the amount of GHGs emitted and/or removed (carbon sequestration) during snail secretion filtrate production for cosmetic uses in a Mediterranean farm where regenerative agriculture is applied.

\section{Materials and Methods}

The authors of the present study performed a carbon footprint (CF) analysis in a Mediterranean snail farming system (Helix aspersa muller) operating under a regenerative agriculture system. The CF analysis was used to measure the total amount of GHGs emitted and removed, along with a supply chain of products within the selected spatial and temporal boundary. The studied farm produces $\mathrm{LX} 360^{\circledR}$, which is a snail secretion filtrate for cosmetic, pharmaceutical, and phytosanitary uses. The GHG emission was quantified, along with the $\mathrm{LX} 360^{\circledR}$ production and soil organic carbon (SOC) stock change following regenerative agriculture. Moreover, the most impactful practices and inputs were identified in order to improve the environmental impact of LX360 ${ }^{\circledR}$ production.

\subsection{Study Area and Snail Farm Description}

The study was performed in the Bianca Experience Farm located in Marsala, Sicily $\left(37^{\circ} 46^{\prime} \mathrm{N} 12^{\circ} 27^{\prime} \mathrm{E}\right)$ in 2021 . The area is characterised by a Mediterranean climate with a 
mean annual temperature of $18^{\circ} \mathrm{C}$ and a mean annual rainfall of $554 \mathrm{~mm}$. Soils are $40 \%$ sand and 18\% clay and are classified as Lithosols according to the word reference base [20]. The soil $\mathrm{pH}$ is 8.2 , and the $\mathrm{CaCO}_{3}$ content is $39 \%$.

For five years (from 2016 to 2021), the farm has followed the principles of circularity economy and regenerative agriculture to reduce external input and improve soil fertility, biodiversity, and the efficiency of natural resources. The farm covers 4 ha on flat land; most of this area is dedicated to snail feed production, and one third of the total area is dedicated to free-range pens for the snails. The soil under free-range pens is permanently covered with Medicago sativa and Trifolium repens, and after every four years, free-range pens will be moved to another farm area. The cover crop was seeded ( $45 \mathrm{~kg}$ of seeds ha ${ }^{-1}$ ) after a surface soil tillage (15 cm soil depth) with a rotatory harrowing in September.

Snails are fed with a mix of Brassicaceae species, Beta vulgaris, Cucurbita maxima, and Vicia faba, Helianthus annus. Each year, $13 \mathrm{t}$ of shredded biomass is supplied to sails. These species are cultivated in the fields near the area of the free-range pens, following organic and regenerative agricultural practices. In total $50 \mathrm{~kg}$ of different seeds are used each year. Minimum tillage is adopted, and roots and plant residues are not removed from the soil. The soil is irrigated by a nozzle spray system only during the drought periods from June to September. During the analyzed period, only three irrigations were applied. Dry organic fertilizer (200 kg each year) was manually distributed.

The snail density in the free-range pens is $0.27 \mathrm{~kg} \mathrm{~m}^{-2}$ at the beginning of rearing period and reaches $0.55 \mathrm{~kg} \mathrm{~m}^{-2}$ after 12 months. Snails that have reached sexual maturity are manually harvested. Before the snail filtrate extraction, snails are hyper-hydrated to guarantee the well-being and quality of the $\mathrm{LX} 360^{\circledR}$ as raw material. Then snails are weighed and washed with an Ozone sanitation system. Finally, after multiple processes of filtration, $\mathrm{LX} 360^{\circledR}$ is packed and stored in $10 \mathrm{~L}$ high density polyethylene (HDPE) food containers.

\subsection{GHG Inventory}

This study has estimated the CF according to the recent ISO guidelines based on standard LCA procedures (ISO/TS 14067:2013; ISO 14026:2017; ISO 14067:2018). The CF was expressed as $\mathrm{CO}_{2}$ equivalent, and the conversion factors for $\mathrm{CH}_{4}$ and $\mathrm{N}_{2} \mathrm{O}$ were used according to the IPCC [21]. This study accounted for a cradle-to-farm gate CF of $1 \mathrm{~L}$ of snail secretion filtrate.

Three stages were identified in the production process: (i) feed production, (ii) rearing management, and (iii) harvest and snail secretion extraction. This analysis did not take into consideration the impact of the distribution or further packaging stages for small quantities. The input and stages are represented in Figure 1. The external input and the energy (fuel, electricity) are referred to as one year of production. The emission of material inputs characterised by more extended durability was accurately divided considering the service lifetime. Life Cycle Inventory (LCI) data for materials and products were selected from Ecoinvent Version 2.2. [22].

Although it consumes resources and emits CO2 in the atmosphere, the effect of human labor on climate change was not included in the LCA and CF analysis.

Emission due to fuel consumption used for the soil management practices (walking tractor and grass cutter) was estimated using the fuel quantity method of the IWCC [23].

The model of Bouwman et al. [24] was used to estimate the NOx emissions resulting from the use of organic nitrogen fertilizer. Soil physical and chemical properties and climate factors were used to determine the soil's NOx emission.

\subsection{Soil Carbon Account}

The soil organic carbon (SOC) change in the soils of the studied snail farm was included in the carbon accounting. After five years since the land-use change (from conventional vineyard to snail farm with regenerative agriculture), the effect on SOC stock change was compared. Three soil samples were collected in the area of the free-range pen in March, in 
the area dedicated to feed production and in the soil of a neighboring vineyard at $0-30 \mathrm{~cm}$ depth ( 3 land uses $\times 3$ replicas $=9$ samples). Soil samples were air-dried and $2 \mathrm{~mm}$ sieved. Soil bulk density was measured using the core method.

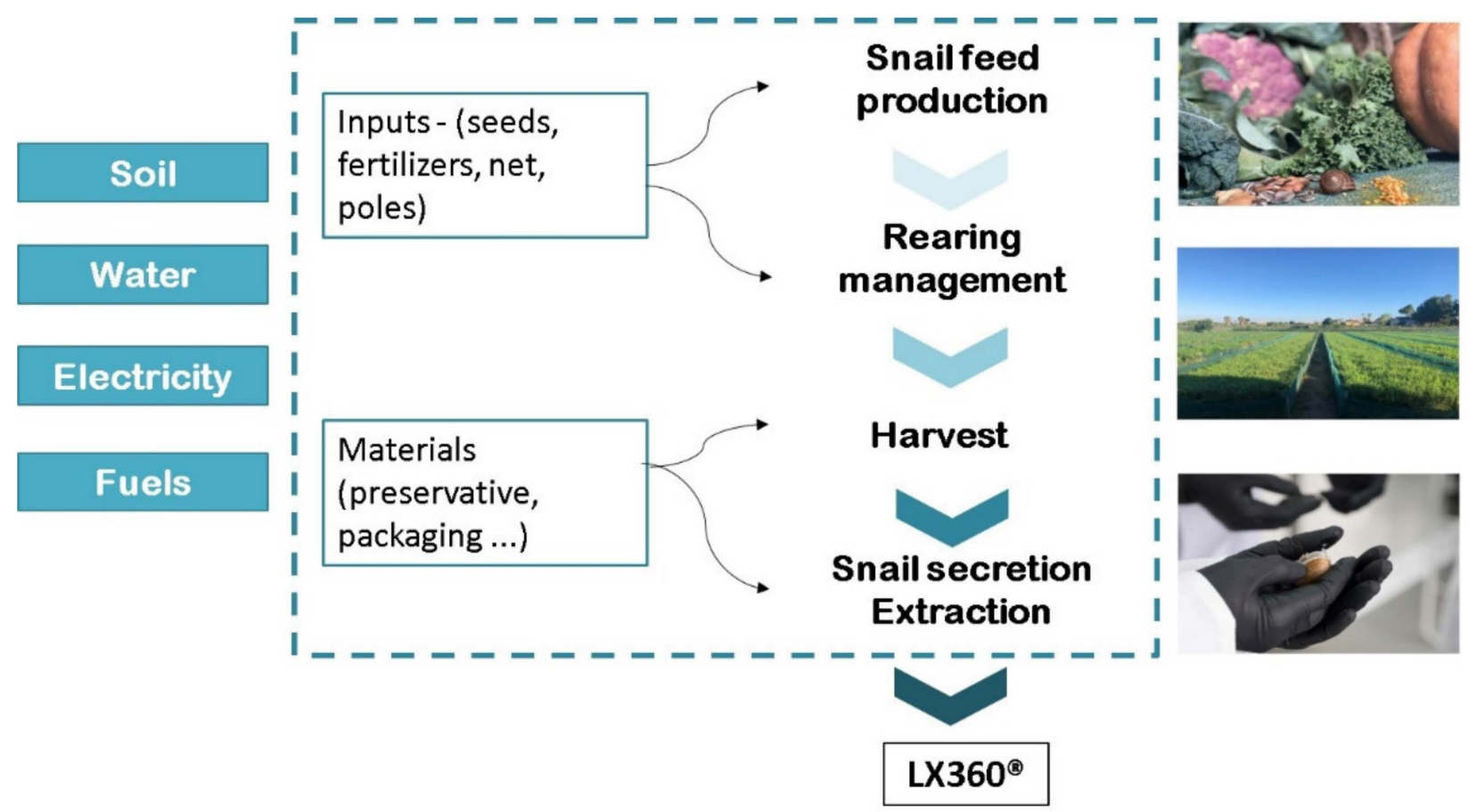

Figure 1. The flowchart of the system boundary of snail secretion filtrate production from cradle-tofarm gate.

Soil organic carbon $\left(\mathrm{g} \mathrm{kg}^{-1}\right)$ was measured according to the Walkley and Black method [25]. SOC data of the selected farm were compared with the SOC content of the neighboring vineyard soil and with a previous soil analysis provided by the farm owner. Soil organic carbon stock was calculated using the measured bulk density, and it was converted to the amount of $\mathrm{CO}_{2}$ sequestered. Soil $\mathrm{CO}_{2}$ emission due to mineralization was calculated using the first-order kinetics model developed by Hénin and Dupuis [26]. For the biomass input into the soil, the specific isohumic coefficients $\left(\mathrm{K}_{1}\right)$ according to Boiffin et al. [27] and Novara et al. [8] were used. The mineralization coefficient $\left(\mathrm{K}_{2}\right)$ was calculated according to Boiffin et al. [27] and Bockstaller and Girardin [28], considering soil texture, air temperature, and limestone content.

Tukey's test for SOC content was performed among soil land use at $p \leq 0.05$ [29].

\section{Results and Discussion}

\subsection{Carbon Footprint Analysis}

The total GHG emission of the snail secretion filtrate (1 L estimated in this case study amounted to $1.76 \mathrm{~kg} \mathrm{CO}_{2} \mathrm{eq} \mathrm{L}^{-1}$. As shown in Figure 2, the snail secretion extraction was the main impacting stage accounting for $1.42 \mathrm{~kg} \mathrm{CO}_{2} \mathrm{eq} \mathrm{L}^{-1}$.

This is mainly due to electricity consumption and only to a small extent to used nets and tanks in high-density polyethene material. Snail feed production and rearing management were the lower contributors, with $12 \%$ and $7 \%$ of incidence on the total emission, respectively. This result contrasted with those observed by Forte et al. [1] and Grossi et al. [30], where the supplementary feeding of snails was the hot spot of the life cycle due to the use of out-farm compost used as organic fertilizer for colza and sunflower yield. 

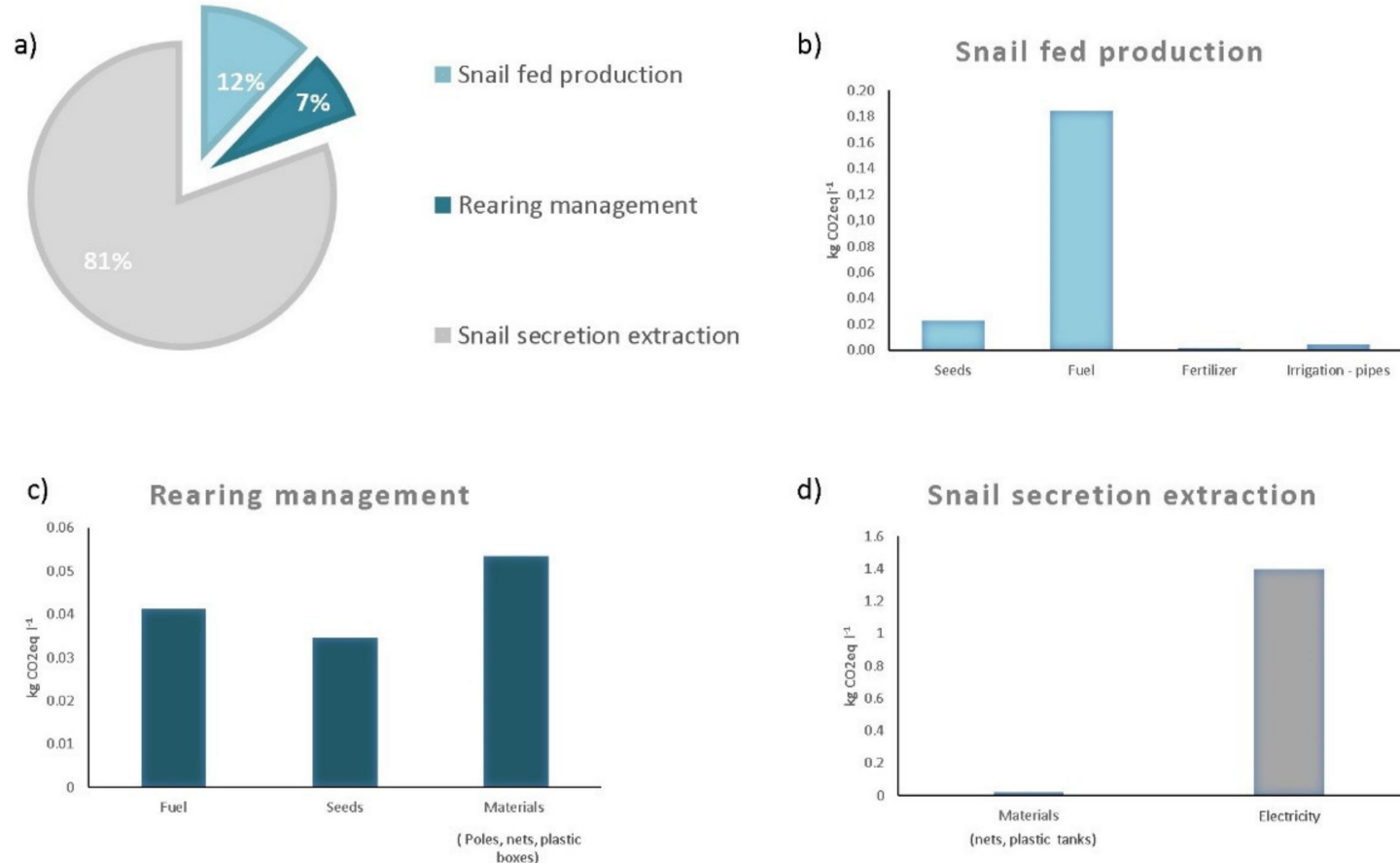

d)

$$
\text { Snail secretion extraction }
$$

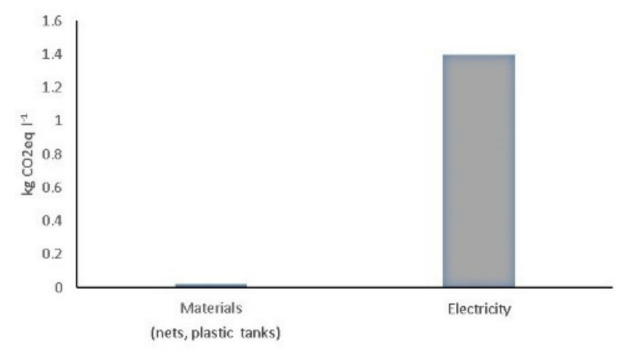

Figure 2. Contribution (\%) of different stages to the total emission (a) and the absolute values of $\mathrm{CO}_{2} \mathrm{eq} \mathrm{L}{ }^{-1}$ of $\mathrm{LX} 360^{\circledR}$ for different items in snail fed production (b), rearing management (c) and snail secretion extraction $(\mathbf{d})$.

In the case study, following the principle of regenerative agriculture, the external inputs (fertilizer, pesticides, seeds) for feed production were negligible. All feeds are cultivated on the farm, and residues return to the soil. Moreover, there is no impact on the transport of supplementary feed. The total emission of the snail feed production stage is $0.21 \mathrm{~kg} \mathrm{CO}_{2} \mathrm{eq} \mathrm{L}^{-1}$. Fuel consumption is the main contributor to the total emissions of this stage, although minimum soil tillage is adopted (Figure 2).

The $\mathrm{CO}_{2}$ emission for the rearing management stage accounted for only $0.13 \mathrm{~kg}$ $\mathrm{CO}_{2} \mathrm{eq} \mathrm{L}^{-1}$ (sum of emission for materials, seed and fuel). In this stage, the emissions are attributed mainly to materials (plastic and wood) for the nets and poles of the pens. The second factor of emission is fuel consumption that is used for grass cutting ( 5 times each year) and the trituration of fed. Details of the emission of each item are shown in Figure 2.

\subsection{Carbon Sequestration}

The study also considered the effect of soil management and land-use change on the total carbon budget in the $\mathrm{CF}$ analysis. After five years since the land-use change, the SOC stock significantly increased in the feed production area and free-range pens. The SOC content was $14.5 \pm 0.8 \mathrm{~g} \mathrm{~kg}^{-1}$ in the neighbour vineyard (Figure 3).

According to the paired site approach [31], this value can be considered at the steadystate level (constant over time), being soil vineyard management in terms of carbon input, yield, and tillage operations has been constant in recent years. It is also confirmed by the similar values found in a soil analysis carried out by the owner of the selected farm five years ago before the vineyard explanting. The land use-change led to a $60 \%$ and $15 \%$ increase of SOC content in free-range pens and feed production areas, respectively, compared to the vineyard soil. Considering a soil depth of $0.20 \mathrm{~m}$ and the farm area, $0.54 \mathrm{Mg} \mathrm{C} \mathrm{y}^{-1}$ were incorporated into the soil in the feed production area and $1.74 \mathrm{MgC} \mathrm{y}^{-1}$ in the freerange pens. 


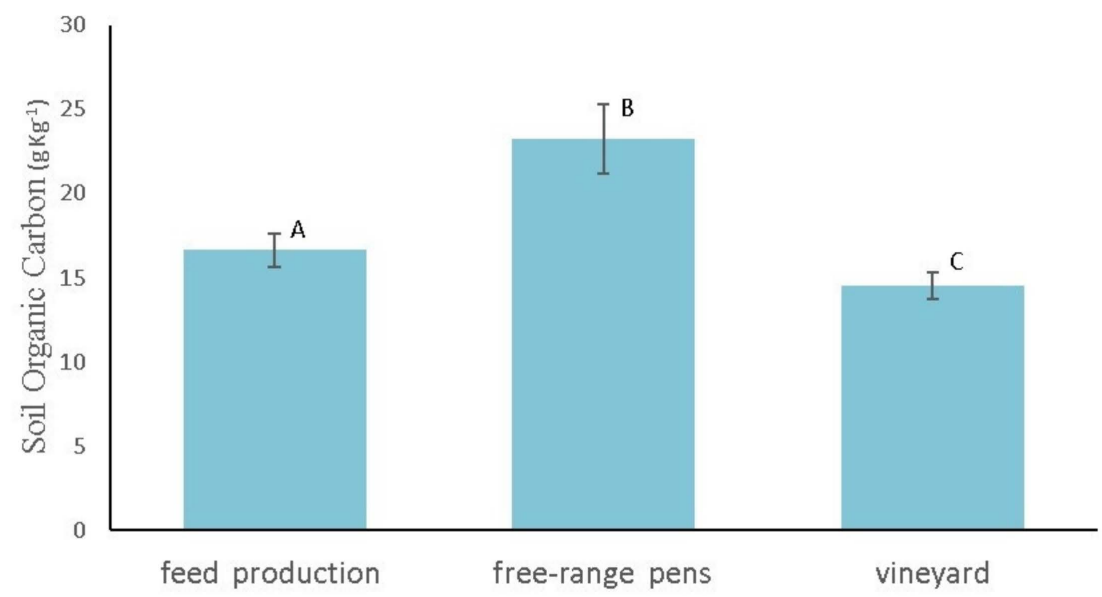

Figure 3. Soil organic carbon content $\left(\mathrm{g} \mathrm{kg}^{-1}\right)$ under vineyard, free-range pens and feed production area. Wiskers indicate standard deviation $(n=5)$. Different letters indicate statistical significance among land uses $(p \leq 0.05)$.

The highest SOC sequestration of the area of the free-range pens can be attributed to the high $C$ input under permanent cover crop, as well as to zero tillage and the increase of the stabilization rate of soil organic matter due to snail excrements. The estimated soil $\mathrm{CO}_{2}$ emission due to organic matter mineralization was 0.32 and $0.34 \mathrm{Mg} \mathrm{C} \mathrm{y}^{-1}$ for the whole area of feed production and free-range pens, respectively.

Being the farm area covered by annual crops, the organic carbon stock in the biomass of cover crop and horticulture species was not considered in the $C$ budget. In this study, the carbon incorporated in the shells in the form of calcium carbonate was not counted because it is difficult to estimate the correct amount of shell that remains in the soil, and the effect of soil inorganic carbon increase can be observed only over a longer time. This contribution is significant, as assessed by Forte et al. [1], who estimated approximately $0.04 \mathrm{~kg}$ of carbon incorporated in the shells as calcium carbonate polymorphs per $\mathrm{kg}$ of harvested snails.

Despite the fact that the $\mathrm{C}$ in the shell was not considered, the findings showed that soil was a net $\mathrm{C}$ sink of atmospheric $\mathrm{CO}_{2}$. The difference between soil carbon sequestration and mineralization led to a positive balance of $1.93 \mathrm{~kg}$ of $\mathrm{CO}_{2} \mathrm{eq} \mathrm{L}^{-1}$ of $\mathrm{LX} 360^{\circledR}$.

This finding confirmed previous studies, which showed the importance of soil as a $\mathrm{C}$ sink in the CF analysis under different land uses such as vineyards and olive groves $[8,32,33]$. The variation of SOC following land-use change is a relevant source of anthropogenic greenhouse gas emissions, contributing about $23 \%$ of the global anthropogenic GHG emissions, and should be included in the carbon account of bioproducts [34,35]. In order to maximize the ability of soil as a carbon sink, more attention should be paid to individuating the agronomic practices that improve the sustainability of the whole agroecosystem and limit the GHG emissions.

\subsection{The CF of LX360 and Future Implication}

The production of $\mathrm{LX} 360^{\circledR}$ does not have a negative impact on climate change; on the contrary, the whole cycle, from snail feed production to extraction stage sequestered $0.17 \mathrm{~kg} \mathrm{CO}_{2} \mathrm{eq} \mathrm{L}^{-1}$ into the soil. Considering the entire production of the studied farm, in total, $522 \mathrm{~kg} \mathrm{CO}$ eq were sequestered from the atmosphere each year. The present work provides an important observation of each production stage, which might help farmers and decision-makers to design the actions necessary to reduce the $\mathrm{CF}$ of snail secretion filtrate. The hot spots of $\mathrm{CO}_{2}$ emission in the selected farm, identified from the life cycle assessment and $\mathrm{CF}$ analysis, were in the last phase of production. The main concern was the use of electricity for the extraction stage, which could be easily reduced through the use of renewable energy. Secondly, the use of material with plastic components for the rearing system could be replaced with more sustainable materials. Moreover, for the feed 
production stage, soil management could be further improved to increase the stabilization of soil organic matter or sequester carbon in woody biomass. The selected farm is planting trees, such as Ceratonia siliqua and Moringa oleifera, that can also contribute to snail feeding.

This study has confirmed the importance of regenerative agriculture in climate change reduction, as well as being assessed by the Intergovernmental Panel on Climate Change, which suggested in the special report "Climate Change and Land" that regenerative agriculture as a sustainable land management practice is effective in building resilience of agro-ecosystems [34]. Regenerative agriculture can increase the soil organic matter content by applying practices such as no-tillage, different cover crops, no external nutrients, no pesticides, and multiple crop rotations [36]. Project Drawdown showed that carbon levels increase from a baseline of 1 to $2 \%$ to up to 5 to $8 \%$ over ten or more years, following regenerative agriculture [37].

There are very few studies related to CF analysis on snail secretion, and those which have analysed the sustainability of natural products used as a raw material in cosmetics are even fewer $[38,39]$. Comparing the impact on climate change of different raw materials is difficult due to the lack of research in this sector and the high difference and variability of ingredient properties. Nevertheless, the cosmetic industry needs to create innovative, sustainable products to be competitive and satisfy the market and consumer demands. As reported by Bom et al., [40] in a review on the sustainability of the cosmetic industry, one of the main goals for the industry is the replacement of unsustainable synthetic ingredients with environmentally friendly products.

The inclusion of natural, organic, or green chemistry-derived ingredients in cosmetics formulations requires greater investigation and evaluation on the functionality and safety of each ingredient, its stability in the formulation, and its performance in what concerns the consumer aesthetic preferences. Additionally, comparative studies between common cosmetic ingredients and sustainable ones should be made to facilitate the exchange.

\section{Conclusions}

One of the main challenges of the cosmetics industry in recent years has been replacing unsustainable synthetic ingredients with sustainable ones. Several studies are evaluating the potential application of natural ingredients in cosmetics, considering functionality, stability in the formulation, and the sustainability of production.

Thanks to the biological properties that are useful for treating skin disorders, snail secretion could be an alternative as a raw material for cosmetic purposes. This research represents an advancement in knowledge, since no studies have been performed on the environmental impact of snail secretion filtrate production. The findings showed the ecosystem service benefits deriving from the supply chain of LX360 ${ }^{\circledR}$, from feed production to snail filtrate extraction. The carbon footprint analysis demonstrated that more carbon is sequestered into the soil compared to the $\mathrm{CO}_{2}$ emissions which occur during the whole production process, and therefore snail secretion has proved a valid alternative to the most common ingredients used in the cosmetics industry.

The benefit to climate change mitigation is derived from feed production and rearing system management stages thanks to the application of regenerative agriculture practices. This study provides new insight into the importance of regenerative agriculture to increase the level of SOC of degraded lands. In particular, further studies could be developed to evaluate the protocol applied in the studied farm in different agroforestry systems as a tool for soil regeneration.

Author Contributions: Conceptualization, A.N. and F.P.; methodology, A.N. and F.P.; data curation, A.N.; writing-original draft preparation, A.N.; writing-review and editing, S.K. and S.S.; visualisation, S.S.; supervision, S.K. and A.N. All authors have read and agreed to the published version of the manuscript.

Funding: This research received no external funding.

Institutional Review Board Statement: Not applicable. 
Informed Consent Statement: Not applicable.

Data Availability Statement: The study did not report any data.

Conflicts of Interest: The authors declare no conflict of interest.

\section{References}

1. Forte, A.; Zucaro, A.; De Vico, G.; Fierro, A. Carbon footprint of heliciculture: A case study from an Italian experimental farm. Agric. Syst. 2016, 142, 99-111. [CrossRef]

2. World-Snails (Except Sea Snails)—Market Analysis, Forecast, Size, Trends and Insights. Available online: https://www. indexbox.io/store/world-snails-except-sea-snails-market-report-analysis-and-forecast-to-2020/ (accessed on 14 February 2022).

3. Peters, G.; Rowley, H.; Wiedemann, S.; Tucker, R.; Short, M.D.; Schulz, M. Red meat production in Australia: Life cycle assessment and comparison with overseas studies. Environ. Sci. Technol. 2010, 44, 1327-1332. [CrossRef]

4. Pelletier, N.; Pirog, R.; Rasmussen, R. Comparative life cycle environmental impacts of three beef production strategies in the Upper Midwestern United States. Agric. Syst. 2010, 103, 380-389. [CrossRef]

5. Beauchemin, K.A.; Janzen, H.H.; Little, S.M.; McAllister, T.A.; McGinn, S.M. Mitigation of greenhouse gas emissions from beef production in western Canada-Evaluation using farm-based life cycle assessment. Anim. Feed Sci. Technol. 2011, 166-167, 663-677. [CrossRef]

6. Apostolou, K.; Staikou, A.; Sotiraki, S.; Hatziioannou, M. An Assessment of Snail-Farm Systems Based on Land Use and Farm Components. Animals 2021, 11, 272. [CrossRef] [PubMed]

7. Mvodo Meyo, E.S.; Nkemasong, Z.A.; Shu, G.; Ngono, J.P.N.; Ngosong, C. Snail Farming as an Alternative Profitable Livestock System for Sustainable Development. In Sustainable Development in Africa; World Sustainability Series; Leal Filho, W., Pretorius, R., de Sousa, L.O., Eds.; Springer: Cham, Switzerland, 2021. [CrossRef]

8. Novara, A.; Favara, V.; Novara, A.; Francesca, N.; Santangelo, T.; Columba, P.; Chironi, S.; Ingrassia, M.; Gristina, L. Soil Carbon Budget Account for the Sustainability Improvement of a Mediterranean Vineyard Area. Agronomy 2020, 10, 336. [CrossRef]

9. Rodale, R. Breaking New Ground: The Search for a Sustainable Agriculture. Futurist 1983, 17, 15-20.

10. LaCanne, C.E.; Lundgren, J.G. Regenerative agriculture: Merging farming and natural resource conservation profitably. PeerJ 2018, 2, e4428. [CrossRef]

11. Soto, R.L.; Martínez-Mena, M.; Cuéllar Padilla, M.; de Vente, J. Restoring soil quality of woody agroecosystems in Mediterranean drylands through regenerative agriculture. Agric. Ecosyst. Environ. 2021, 306, 107191. [CrossRef]

12. Morugán-Coronado, A.; Linares, C.; Gómez-López, M.D.; Faz, Á.; Zornoza, R. The impact of intercropping, tillage and fertiliser type on soil and crop yield in fruit orchards under Mediterranean conditions: A meta-analysis of field studies. Agric. Syst. 2020, 178, 102736. [CrossRef]

13. Vicente-Vicente, J.L.; García-Ruiz, R.; Francaviglia, R.; Aguilera, E.; Smith, P. Soil carbon sequestration rates under Mediterranean woody crops using recommended management practices: A meta-analysis. Agric. Ecosyst. Environ. 2016, 235, 204-214. [CrossRef]

14. Aguilera, E.; Lassaletta, L.; Gattinger, A.; Gimeno, B.S. Managing soil carbon for climate change mitigation and adaptation in Mediterranean cropping systems: A meta-analysis. Agric. Ecosyst. Environ. 2013, 168, 25-36. [CrossRef]

15. Available online: https://www.globenewswire.com/en/search/organization/Prophecy\%2520Market\%2520insights (accessed on 14 February 2022).

16. Juhász, M.L.W.; Levin, M.K.; Marmur, E.S. The use of natural ingredients in innovative Korean cosmeceuticals. J. Cosmet. Dermatol. 2018, 17, 305-312. [CrossRef] [PubMed]

17. Di Filippo, M.F.; Panzavolta, S.; Albertini, B.; Bonvicini, F.; Gentilomi, G.A.; Orlacchio, R.; Passerini, N.; Bigi, A.; Dolci, L.S. Functional properties of chitosan films modified by snail mucus extract. Int. J. Biol. Macromol. 2020, 143, 126-135. [CrossRef]

18. Pons, F.; Koenig, M.; Michelot, R.; Mayer, M.; Frossard, N. The bronchorelaxant effect of helicidine, a Helix pomatia extract, involves prostaglandin E2 release. Pharmaceut. Biol. 1998, 36, 13-19. [CrossRef]

19. Ellijimi, C.; Ben Hammouda, M.; Othman, H.; Moslah, W.; Jebali, J.; Mabrouk, H.B.; Morjen, M.; Haoues, M.; Luis, J.; Marrakchi, N.; et al. Helix aspersa maxima mucus exhibits antimelanogenic and anti-tumoral effects against melanoma cells. Biomed. Pharmacother. 2018, 101, 871-880. [CrossRef] [PubMed]

20. WRB-IUSS Working Group. World Reference Base for Soil Resources. World Soil Resources Reports No. 103, 92-5-105511-4; FAO: Rome, Italy, 2006.

21. IPCC. 2006 Guidelines for National Greenhouse Gas Inventories-Volume 4: Agriculture, Land Use and Forestry (GL-AFOLU). Available online: http:/ / www.ipcc-nggip.iges.or.jp/public/2006gl/vol4.html (accessed on 14 February 2022).

22. Ecoinvent Version 2.2. The Ecoinvent Database Is a Compilation of Life Cycle Inventory (LCI) Data for Materials and Products; Competence Centre of the Swiss Federal Institute of Technology: Zürich, Switzerland, 2011. Available online: www.ecoinvent.org (accessed on 14 February 2022).

23. International Wine Carbon Calculator Protocol-Version 1.2. Available online: https://www.ipw.co.za/content/pdfs/ghg/eng/ International_Wine_Carbon_Calculator_Protocol_V1.2.pdf (accessed on 14 February 2022).

24. Bouwman, A.F.; Boumans, L.J.M.; Batjes, N.H. Modelling global annual $\mathrm{N}_{2} \mathrm{O}$ and $\mathrm{NO}$ emissions from fertilised fields. Glob. Biogeochem. Cycles 2002, 16, 1080-1089. [CrossRef] 
25. Walkley, A.; Black, I.A. An Examination of the Degtjareff Method for Determining Soil Organic Matter, and a Proposed Modification of the Chromic Acid Titration Method. Soil Sci. 1934, 37, 29-38. [CrossRef]

26. Hénin, S.; Dupuis, M. Essai de bilan de la matière organique du sol. Balance of soil organic matter. Ann. Agron. 1945, 15, 17-19. (In French)

27. Boiffin, J.; Keli Zagbahi, J.; Sebillotte, M. Systèmes de culture et statut organique des sols dans le Noyonnais: Application du modèle de Hénin-Dupuis. Cropping systems and soil organic status in the Noyonnais: Application of the Hénin-Dupuis model. Agronomie, EDP. Sciences 1986, 6, 437-446. (In French)

28. Bockstaller, C.; Girardin, P. How to validate environmental indicators? Agric. Syst. 2003, 76, 639-653. [CrossRef]

29. IBM Corp. IBM SPSS Statistics for Windows, Version 20.0; IBM Corp: Armonk, NY, USA, 2011.

30. Grossi, G.; Chiriacò, M.V.; Castaldi, S.; Valentini, R. Carbon footprint of snail meat: A case study from an Italian organic outdoor rearing. In Proceedings of the 10th Convegno dell' Associazione Rete Italiana LCA 2016, Ravenna, Italy, 23-24 June 2016; ISBN 978-88-8286-333-3.

31. Novara, A.; La Mantia, T.; Barbera, V.; Gristina, L. Paired-site approach for studying soil organic carbon dynamics in a Mediterranean semiarid environment. Catena 2012, 89, 1-7. [CrossRef]

32. Smith, P.; Adams, J.; Beerling, D.J.; Beringer, T.; Calvin, K.V.; Fuss, S.; Griscom, B.; Hagemann, N.; Kammann, C.; Kraxner, F.; et al. Land-Management Options for Greenhouse Gas Removal and Their Impacts on Ecosystem Services and the Sustainable Development Goals. Annu. Rev. Environ. Resour. 2019, 44, 255-286. [CrossRef]

33. Smith, P.; Keesstra, S.D.; Silver, W.L.; Adhya, T.K.; De Deyn, G.B.; Carvalheiro, L.G.; Giltrap, D.L.; Renforth, P.; Cheng, K.; Sarkar, B.; et al. Soil-derived Nature's Contributions to People and their contribution to the un Sustainable Development Goals. Philos. Trans. R. Soc. B Biol. Sci. 2021, 376, 20200185. [CrossRef]

34. IPCC. Climate Change and Land: An IPCC Special Report on Climate Change, Desertification, Land Degradation, Sustainable Land Management, Food Security, and Greenhouse Gas Fluxes in Terrestrial Ecosystems. 2019. Available online: https: //www.ipcc.ch/site/assets/uploads/2019/11/SRCCL-Full-Report-Compiled-191128.pdf (accessed on 14 February 2022).

35. Houghton, R.A.; Nassikas, A.A. Global and regional fluxes of carbon from land use and land cover change 1850-2015. Glob. Biogeochem. Cycles 2012, 31, 456-472. [CrossRef]

36. Newton, P.; Civita, N.; Frankel-Goldwater, L.; Bartel, K.; Johns, C. What is regenerative agriculture? A review of scholar and practitioner definitions based on processes and outcomes. Front. Sustain. Food Syst. 2020, 4, 577723. [CrossRef]

37. Project Drawdown. Regenerative Annual Cropping. 2020. Available online: https://www.drawdown.org/solutions/ regenerative-annual-cropping (accessed on 14 February 2022).

38. Glew, D.; Lovett, P.N. Life cycle analysis of shea butter use in cosmetics: From parklands to product, low carbon opportunities. J. Clean. Prod. 2014, 68, 73-80. [CrossRef]

39. Francke, I.C.M.; Castro, J.F.W. Carbon and water footprint analysis of a soap bar produced in Brazil by Natura Cosmetics. Water Resour. Ind. 2013, 1-2, 37-48. [CrossRef]

40. Bom, S.; Jorge, J.; Ribeiro, H.M.; Marto, J. A step forward on sustainability in the cosmetics industry: A review. J. Clean. Prod. 2019, 225, 270-290. [CrossRef] 